\title{
Plate Wastage and the Service Quality of the Cafeteria in a Private High School
}

\author{
Kent Serafin N. Francisco ${ }^{1}$, Gerald Z. Macalinao ${ }^{2}$, Ranny Magdalena J. Satigi ${ }^{3}$, Ruchel G. \\ Oasan $^{4}$ \\ Adventist University of the Philippines \\ rgoasan@aup.edu.ph
}

\begin{abstract}
Millions of people in the world are suffering from scarcity of food, yet tons of food are wasted every day. This study was conducted to determine the food wastage of high school students and the service quality of a cafeteria located in Silang, Cavite. Convenience sampling was utilized to select high school students enrolled in the school where the cafeteria is situated to participate in the study. A descriptive-evaluative research design was used and data gathered were analyzed using descriptive statistics such as frequency, mean, and standard deviation. Quarter waste method was used to measure plate wastage while adopted questionnaire was used to determine the service quality of the cafeteria. Findings revealed that the highest percentage of food wastage was gluten followed by ground vegescallop, vegemeat, tofu, and beans. In terms of service quality, the lowest percentage was the dining area (Mean=2.95 and $\mathrm{SD}=0.80$ ), followed by Food Quality (Mean=3.44 and $\mathrm{SD}=0.80$ ), Food Variety (Mean= 3.76 and $\mathrm{SD}=0.61$ ), Personnel employees' service (Mean=3.80 and $\mathrm{SD}=0.79$ ), and Serving time (Mean=3.85 and $\mathrm{SD}=0.80$ ). Among the five protein foods that incurred a leftover, gluten has the highest percentage of waste while among the five factors contributing to the service quality of a cafeteria, dining area has the lowest percentage. Based on the results, the use of gluten as part of the meal and the dining area as a place to eat should be improved to lessen the food wastage and enhance the service quality, respectively.
\end{abstract}

Keywords: plate wastage; service quality; cafeteria; food waste; Quarter Waste Method.

\section{INTRODUCTION}

Millions of people in the world are suffering in the world are suffering from scarcity of food, yet tons of food are wasted every day. In developed countries, while housholds represent a significant source of food waste, the institutional food service sectors such as schools, prisons, and the hospitals are also major sources of food waste (Wilkie, Graunke \& Cornejo, 2015). Cafetaria is one of the most important establisments in any university, many students rely primarily in the cafetaria for their food to eat especially at luch therefore quality of service must be considered. Students eat in cafetaria for several reasons such as the food itself, the price on the food, and the ambience. 
According to Cohen, Richardson, Parker, Catalano, and Rimm (2015), acceptance of school cafetaria services is determined by the percentage of food eaten or wasted by the school community particularly the students who composed the bulk of the population. Moreover, measuring food waste in the school cafetarias is a necessary part of an evaluation of the effectiveness of schools policies and interventions designed to amplify consumption of healthier meals and to reduce meals waste in schools ( Getts, Quinn, Johnson, and Otten, 2017). Thus, this study aimed to determine the food wastage of high school students and the service quality of a cafetaria.

\section{University food service/Cafeteria}

Cafeteria and food service programs are recognized as one of the determinants for students' retention at university level. A university cafeteria with variety, diversity, and comfort causes students to experience a sense of "home" while on campus where they can engage in longer leisurely conversation that permits loud interactive activities among peers (Chang, Suki, \& Suki, 2015). University food service becomes one of the services that need to be considered in order to gratify students by providing foods in universities (Zainol \& Seladorai, 2016).

\section{Food Waste}

Each year, an estimated 1/3 of all food produced for human consumption is lost or wasted world-wide. In Europe and North America is $95-115 \mathrm{~kg} /$ year while in sub- Saharan Africa and Southeast Asia is 6-11 kg/ year (FAO, 2011). In the study of Hanks, Wansink, and Just (2013), three different methods were used to measure food waste to the most convenient, less time, and cost effective: (a) Half-Waste Method: All, some, or None food waste; (b) QuarterWaste Method: All, 3/4, 1/2, or $1 / 4$ of a food wasted; and (c) Photograph Method: $10 \%$ increments should be wasted using photographed. Among the three methods, Quarter-waste method is the highest in terms of reliability and found to be the most accurate.

\section{Food Quality}

Food quality is related to satisfaction with the quality of fast food served to customers (Chang, Suki, \& Suki, 2015). In several empirical studies, food quality has emerged as the most essential key attribute of customer satisfaction. There are various attributes of food quality which had been discussed in past researches. These includes taste, health options, freshness, presentation, quality of ingredients, safety, portion, halal, nutrition, menu variety, aroma, temperature, innovative menu items, hygiene, authentic food and texture (Zainol \& Seladorai, 2016).

\section{Serving Time}


Rioux, Schmitt, and Leclerc (2016) stated, waiting can be time-consuming, annoying, and incredibly frustrating. First, unoccupied time of the students in the waiting line is always felt longer than the occupied time. If a student in service waiting line is engaged with some activity by himself or by service personnel, he will not feel waiting as longer. One of the funny but practical suggestions is to provide a big mirror where people must wait in standing for longer. This is nothing but the subjective element of the students as they not occupied by any activity in the line. Second, preprocess waits of the students is always felt as longer by students than in- process waits. Obviously, the students do not take cognizance of longer time involved in the service delivery process as long as he is actively participating in the process. Third, any anxiety on the part of the students make him to feel waiting time as subjectively longer (Edwards, 2016).

\section{Food variety}

Variation gave a lot of improvement to the food service because customers satisfaction is low when it comes to service but because of the assorted foods in the counter with beverages, customer satisfaction became high and food waste reduced (Ahmad, 2015). Food variety is important for satisfaction. Variety does not only referred to sensory variety within a meal, but also variety between meals, in meal offerings (Andersen \& Hyldig, 2015). The biggest challenge food service establishments are facing today is meeting the nutritional requirements the students need and getting them to actually eat what they serve. School food service should offer food that tastes good to the students being served; foods that support their growth and development, meeting their nutritional needs; and exposing them to a variety of foods. If food service establishments have to increase students' familiarity with foods that are both healthy and tasty, they are to be more likely to incorporate these foods into their diets.

\section{Personnel Service}

The server is also an important part of the segment of the food service experience. They are the face of the food service. Personnel should maintain a high degree of personal cleanliness and should conform to good hygienic practices during all working periods. Apart from personal hygiene, the students also expect prompt and courteous service from them. When every employee strives to provide $100 \%$ customer satisfaction, every customer, every visitcustomers will keep coming back for more. Feeling and impressions upon leaving the place have a lasting influence on whether or not they will return (Duong, 2015).

\section{Ambiance}


In the food service industry, ambiance is a term used to refer to the aesthetic or emotional impact of an establishment on its customers. It has any number of elements- sanitation, ventilators, cleanliness, furnishings, lighting, sound, decoration, themes, table settings, employees' appearances and attitudes, and so on- all aspects of the establishment's environment. In a professionally designed restaurant, the ambiance is never left to chance. It is carefully crafted to achieve a particular impact (Dipesh \& Apil, 2018). Cleanliness of the food service also matters. It is important that the food service provides a clean, comfortable environment especially suited for the students. They also need to provide a warm and inviting environment and a variety of comfortable seating arrangements to accommodate anyone- from a single person to a group of students (Senduk, Saerang, \& Lambey, 2016).

\section{METHODS}

\section{Research Design}

This study used descriptive-evaluative method, a type of descriptive research design used to collect the data to describe and evaluate or measure the results against some known or hypothesized standards. This design is best suited for this study because it measures the food wastage and factors influencing customer satisfaction towards the service quality of the cafeteria.

\section{Instruments}

Quarter-Waste method was used to determine the plate wastage by measuring one whole $(100 \%), 3 / 4(75 \%), 1 / 2(50 \%)$, and $1 / 4(25 \%)$ and camera was used for documentation of leftover food. A Quality Service Questionnaire was used to determine the service quality of the cafeteria. Composition of the questionnaire used was to describe the extent quality of service at cafeteria such as: Serving Time, Personnel Employee Service, Food Variety, Food Quality and Dining Area.

\section{Population and Sampling Techniques}

The participants of the study were 132 high school students of a private academy in Silang, Cavite during the school year 2018-2019. Participants were selected by convenience sampling, a non- probability sample that is based on characteristics of a population and the objective of the study. A convenience sample is a non-probability sample in which the researcher uses the subjects that are nearest and available to participate in the research study. This technique is also referred to as "accidental sampling," and is commonly used in pilot studies prior to launching a larger research project (Crossman, 2019). 


\section{Data Gathering Procedure}

The researchers used the menu in the cafeteria which focused only on one category which is the protein-rich foods, these are the entrée and beans served during lunch time at the extension lane of the said cafeteria. The researchers were referred to the menu as a guideline of the food to be served during that day. The researchers asked the respondents to leave their plate on the table after they were done eating, then the researchers examined each plate using QuarterWaste method. Quarter-waste method is a technique use for calculating accurate amounts of tray waste (Hanks, Wansink, \& Just, 2013). It is a visual method that reports whether none, $1 / 4$, $1 / 2,3 / 4$, or all of the food item is wasted. On the fifth day of observation, the researchers distributed adopted Quality Service Questionnaire to gather data. After gathering all the 132 questionnaires, the researchers tallied the results, and they were analyzed by the experts, as 123 questionnaires were validated.

\section{RESULTS}

Food Wastage of the High School Students

Table 1. Food Waste of High School Students

\begin{tabular}{|l|l|l|}
\hline Vege-product & f & Percentage \\
\hline Gluten & 28 & $62.2 \%$ \\
Ground Vege-Scallop & 4 & $8.9 \%$ \\
Vege-meat & 4 & $8.9 \%$ \\
Beans & 3 & $6.7 \%$ \\
Tofu & 6 & $13.3 \%$ \\
Total & 45 & $100 \%$ \\
\hline
\end{tabular}

Table 1 shows the composition of vege-products wastage of high school students in the cafeteria regardless of the measurement. More than half of the accumulated left overs was from gluten dishes which is $62.2 \%$. 


\section{Food Waste on Gluten}

Table 2. Gluten Waste

\begin{tabular}{lll}
\hline & f & Percentage \\
\hline No Left Over & 127 & $81.9 \%$ \\
1 & 6 & $3.9 \%$ \\
$3 / 4$ & 1 & $0.6 \%$ \\
$1 / 2$ & 2 & $1.3 \%$ \\
$1 / 4$ & 19 & $12.3 \%$ \\
\hline Total & $\mathbf{1 5 5}$ & $\mathbf{1 0 0 \%}$ \\
\hline
\end{tabular}

Table 2 shows the food wastage of gluten dish wherein a total of 155 students ordered the food. Results show that 127 (81.9\%) students finished the food having no leftovers, while six (3.9\%) students wasted one whole serving. The quantity waste with highest percentage is $1 / 4$ serving wasted by $19(12.3 \%)$ students followed by $1 / 2$ serving wasted by two (1.3\%) students, and lastly $3 / 4$ serving wasted by one (0.6\%) student only.

\section{Food Waste on Ground Vege-Scallop}

Table 3 shows the wastage of protein food namely ground scallop. There were 131 students who ordered and three (2.3\%) students wasted $1 / 4$ serving of ground scallop, followed by $1 / 2$ serving wasted by one $(.8 \%)$ student.

\section{Table 3. Ground Vege-Scallop Waste}

\begin{tabular}{lll}
\hline & f & Percentage \\
\hline No Left Over & 127 & $96.9 \%$ \\
1 & 0 & 0 \\
$3 / 4$ & 0 & 0 \\
$1 / 2$ & 1 & $0.8 \%$ \\
$1 / 4$ & 3 & $2.3 \%$ \\
\hline Total & 131 & $100 \%$ \\
\hline
\end{tabular}

\section{Food Wastage on Vege Meat}

Table 4 shows the wastage of vege-meat food, out of 131 students that ordered the said vegeproduct, $127(95.5 \%)$ do not have left overs, while three $(3.8 \%)$ of the students wasted $1 / 2$ serving of vege meat and one $(0.8 \%)$ student wasted $3 / 4$ serving. 
Table 4. Vege-Meat Waste

\begin{tabular}{lll}
\hline & $\mathbf{f}$ & Percentage \\
\hline No Left Over & 127 & $95.4 \%$ \\
1 & 0 & 0 \\
$3 / 4$ & 1 & 0.8 \\
$1 / 2$ & 3 & $3.8 \%$ \\
$1 / 4$ & 0 & 0 \\
\hline Total & $\mathbf{1 3 1}$ & $\mathbf{1 0 0 \%}$ \\
\hline
\end{tabular}

\section{Food Wastage on Beans}

Table 5 shows the wastage of beans. Total of students who ordered beans is 130 students, 127 $(97.7 \%)$ do not have left overs, two $(1.6 \%)$ of the students wasted $1 / 2$ serving and one $(0.8 \%)$ student wasted $1 / 4$ serving of Beans.

Table 5. Beans Waste

\begin{tabular}{lll}
\hline & f & Percentage \\
\hline No Left Over & 127 & $97.7 \%$ \\
1 & 0 & 0 \\
$3 / 4$ & 0 & 0 \\
$1 / 2$ & 2 & $1.5 \%$ \\
$1 / 4$ & 1 & 0.8 \\
\hline Total & $\mathbf{1 3 0}$ & $\mathbf{1 0 0 \%}$ \\
\hline
\end{tabular}

\section{Food Wastage on Tofu}

Table 6 shows the wastage of protein food namely tofu. Total number of students who ordered tofu is 133 and students who do not have left overs were 127 (95.5\%). Six (4.5\%) of the 133 wasted $1 / 4$ serving of the product. There were no left overs in the quantity of one whole serving, three- fourth serving, and one- half serving.

Table 6. Tofu Waste

\begin{tabular}{lll}
\hline & f & Percentage \\
\hline No Left Over & 127 & $95.5 \%$ \\
1 & 0 & 0 \\
$3 / 4$ & 0 & 0 \\
$1 / 2$ & 0 & 0 \\
$1 / 4$ & 6 & $4.5 \%$ \\
\hline Total & $\mathbf{1 3 3}$ & $\mathbf{1 0 0 \%}$ \\
\hline
\end{tabular}




\section{Extent of the Service Quality of the University Cafeteria}

The succeeding tables show the result of food service quality questionnaire that were distributed at the second week of observation.

\section{Quality of Service in Terms of Serving Time}

\section{Table 7. Serving Time}

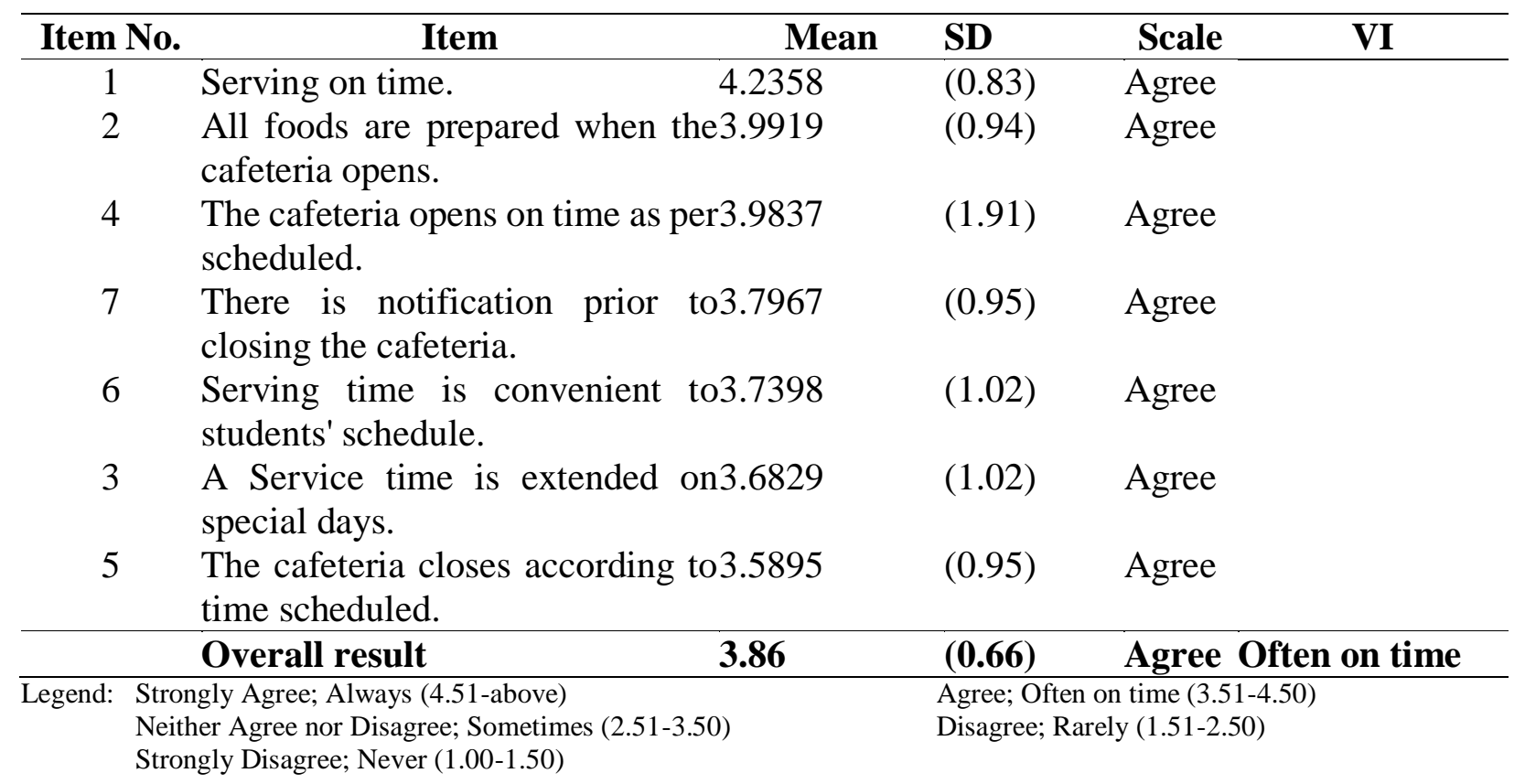

Table 7 presented above shows that all of the items under Serving Time is scaled as agree with a mean of 3.86 and verbal interpretation of often on time. While Table 8 presents the respondents' answer to the quality of service in the cafeteria in terms of personnel service. It shows that all of the items were answered and interpreted as agree and moderately satisfied respectively with the mean of 3.8 .

\section{Quality of service in Terms of Personnel Service}

Table 8 presented below shows the quality of service in terms of food quality served in the cafeteria. The overall mean is 3.4 which means the respondents are moderately satisfied with the quality of food being served. While Table 9 presents the quality of service in terms of food variety. Four out of the six items have the scale of neither agree nor disagree, thus the mean is 3.4 with the interpretation of satisfied.

Table 8. Personnel Services

\begin{tabular}{l|l|l|l|l}
\hline Item No. Item & Mean & SD & Scale & VI \\
\hline
\end{tabular}




\begin{tabular}{|c|c|c|c|c|c|}
\hline 1 & Cafeteria personnel are properly groomed. & 4.1463 & $(0.74)$ & Agree & \\
\hline 5 & Taking orders from customer. & 3.8293 & $(1.01)$ & Agree & \\
\hline 4 & Prompt in assisting customer. & 3.8130 & $(0.99)$ & Agree & \\
\hline 7 & Speaks clearly. & 3.8130 & $(0.84)$ & Agree & \\
\hline 6 & Helpful in assisting customers. & 3.7642 & $(0.81)$ & Agree & \\
\hline 8 & Help resolve customer needs. & 3.7561 & $(0.84)$ & Agree & \\
\hline 3 & Good attitude towards customer. & 3.7154 & $(0.79)$ & Agree & \\
\hline \multirow[t]{2}{*}{2} & Knowledgeable on the food being served. & 3.5772 & $(0.97)$ & Agree & \\
\hline & Overall result & 3.8 & (0.61) & Agree & Moderately satisfied \\
\hline & $\begin{array}{l}\text { Strongly Agree; Very Much Satisfied (4.5-above) } \\
\text { Neither Agree nor Disagree; Satisfied (2.51-3.50) } \\
\text { Strongly Disagree; Not Satisfied (1.00-1.50) }\end{array}$ & $\begin{array}{l}\mathrm{Ag} \\
\mathrm{Di}\end{array}$ & $\begin{array}{l}\text {; Modera } \\
\text { ree; Sligh }\end{array}$ & $\begin{array}{l}\text { ely Satisfie } \\
\text { ly Satisfie }\end{array}$ & $\begin{array}{l}d(3.51-4.50) \\
(1.51-2.50)\end{array}$ \\
\hline
\end{tabular}

\section{Quality of service in Terms of Food Quality Served in the Cafeteria}

\section{Table 9. Food Quality}

\begin{tabular}{|c|c|c|c|c|c|}
\hline \multicolumn{2}{|c|}{ Item No. Items } & \multirow{2}{*}{$\begin{array}{l}\text { Mean } \\
3.7967\end{array}$} & \multirow{2}{*}{$\begin{array}{l}\text { SD } \\
(0.99)\end{array}$} & \multirow{2}{*}{\begin{tabular}{|l|} 
Scale \\
Strongly Agree
\end{tabular}} & \multirow[t]{2}{*}{ VI } \\
\hline 3 & Food served are healthy. & & & & \\
\hline 1 & $\begin{array}{l}\text { Food served are prepared under } \\
\text { sanitary conditions. }\end{array}$ & 3.7317 & $(1.05)$ & Strongly Agree & \\
\hline 5 & Cold food is served cold. & 3.4878 & $(1.08)$ & $\begin{array}{l}\text { Neither Agree nor } \\
\text { Disagree }\end{array}$ & \\
\hline 2 & Food served are delicious. & 3.3496 & $(1.08)$ & $\begin{array}{l}\text { Neither Agree nor } \\
\text { Disagree }\end{array}$ & \\
\hline 4 & Hot food served hot. & 3.2195 & $(1.13)$ & $\begin{array}{l}\text { Neither Agree nor } \\
\text { Disagree }\end{array}$ & \\
\hline 6 & Most food served are not oily. & 3.0650 & $(1.26)$ & $\begin{array}{l}\text { Neither Agree nor } \\
\text { Disagree }\end{array}$ & \\
\hline & Overall result & 3.4 & $(\mathbf{0 . 8 0})$ & $\begin{array}{l}\text { Neither Agree nor } \\
\text { Disagree }\end{array}$ & Satisfied \\
\hline & $\begin{array}{l}\text { ngly Agree; Very Much Satisfied (4.5- } \\
\text { her Agree nor Disagree; Satisfied (2.5 } \\
\text { ngly Disagree; Not Satisfied (1.00-1.5 }\end{array}$ & $\begin{array}{l}\text { above) } \\
(-3.50)\end{array}$ & $\begin{array}{l}\text { Agree; } \\
\text { Disagr }\end{array}$ & $\begin{array}{l}\text { Aoderately Satisfied (3.51-4.50) } \\
\text {; Slightly Satisfied (1.51-2.50) }\end{array}$ & \\
\hline
\end{tabular}

\section{Quality of service in Terms of Food Variety Served in the Cafeteria}

\section{Table 10. Food Variety}

\begin{tabular}{clccc}
\hline Item No.Items & Mean & SD & Scale & VI \\
\hline 1 & $\begin{array}{l}\text { Food being served offer variety of choices (main dish, } \\
\text { vegetable dish, pasta,etc.). }\end{array}$ & 4.0325 & $(0.90)$ & Agree \\
4 & $\begin{array}{l}\text { There is variety of texture in food items (soft, crunchy, } \\
\text { chewy, etc.). } \\
\text { There is variety of taste in food items (salty, sweet sour, } \\
\text { bitter). } \\
\text { There is variety of appearance in food items (different } \\
\text { color/presentation) }\end{array}$ & 3.73980 & $(0.96)$ & Agree \\
5 & Agree & Agree
\end{tabular}




\begin{tabular}{clccc}
2 & Serving local and international cuisine. & 3.5366 & $(1.09)$ & Agree \\
\hline & Overall result & $\mathbf{3 . 7 6}$ & $\mathbf{( 0 . 7 9 )}$ & $\begin{array}{r}\text { Agree } \\
\text { Very } \\
\text { Good }\end{array}$ \\
\hline Legend: & $\begin{array}{l}\text { Strongly Agree; Excellent (4.5-above) } \\
\text { Neither Agree nor Disagree; Good (2.51-3.50) } \\
\text { Strongly Disagree; Poor (1.00-1.50) }\end{array}$ & $\begin{array}{l}\text { Agree; Very Good (3.51-4.50) } \\
\text { Disagree; Fair (1.51-2.50) }\end{array}$ & \\
& &
\end{tabular}

\section{Quality service in Terms of Dining Area in the Cafeteria}

Table 11. Dining Area

\begin{tabular}{|c|c|c|c|c|c|}
\hline $\begin{array}{l}\text { Item } \\
\text { No. }\end{array}$ & Item & Mean & SD & Scale & VI \\
\hline 1 & The dining area is clean. & 3.9024 & $(1.05)$ & Agree & \\
\hline 2 & $\begin{array}{l}\text { The dining area is attractively } \\
\text { structured. }\end{array}$ & 3.2602 & $(1.10)$ & $\begin{array}{l}\text { Neither Agree } \\
\text { nor Disagree }\end{array}$ & \\
\hline 3 & $\begin{array}{l}\text { The cafeteria provides cozy } \\
\text { environment. }\end{array}$ & 2.9268 & $(1.15)$ & $\begin{array}{l}\text { Neither Agree } \\
\text { nor Disagree }\end{array}$ & \\
\hline 4 & $\begin{array}{l}\text { The school cafeteria is well } \\
\text { ventilated. }\end{array}$ & 2.8943 & $(1.19)$ & $\begin{array}{l}\text { Neither Agree } \\
\text { nor Disagree }\end{array}$ & \\
\hline 5 & $\begin{array}{l}\text { The cafeteria provides comfortable } \\
\text { seating environment. }\end{array}$ & 2.8537 & $(1.21)$ & $\begin{array}{l}\text { Neither Agree } \\
\text { nor Disagree }\end{array}$ & \\
\hline 6 & Music is played during dining time. & 1.9024 & $(1.22)$ & Disagree & \\
\hline & Overall result & 2.96 & $(\mathbf{0 . 8 0})$ & $\begin{array}{c}\text { Neither Agree } \\
\text { nor Disagree }\end{array}$ & Good \\
\hline Legend: & $\begin{array}{l}\text { Strongly Agree; Excellent (4.5-above) } \\
\text { Neither Agree nor Disagree; Good (2.51-3.50) } \\
\text { Strongly Disagree; Poor (1.00-1.50) }\end{array}$ & & $\begin{array}{l}\text { Very Go } \\
\text {; Fair }\end{array}$ & $\begin{array}{l}3.51-4.50) \\
2.50)\end{array}$ & \\
\hline
\end{tabular}

Table 11 shows the mean of the quality service in terms of dining area. The result was dining area in the cafeteria is good with the mean of 2.96 for almost all of the items has a result of neither agree nor disagree and a verbal interpretation of good. In addition, the $S D$ is 0.80 , stating that there answers were not far from each other.

\section{DISCUSSION}

\section{Food Wastage of the High School Students}

The observation of wastage of vege-products used were done in eight days using the QuarterWaste Method. Among the vege-products used and observed, gluten has the highest waste as shown in Table 1. And the least waste were beans and tofu. In Table-2, the number of students who have left overs in gluten dish are shown with six, one, two, and 19 students having leftovers of one whole, $3 / 4,1 / 2$, and $1 / 4$ servings respectively. In Table 3, 96.9\% of students have no leftover in scallop. The serving with the highest waste percentage is $1 / 4$ serving $(2.3 \%)$ 
followed by $1 / 2$ serving with the percentage of $0.8 \%$ (only one student). While the highest amount of waste in vege-meat as shown in Table-4 was $1 / 2$ serving with a percentage of $3.8 \%$ or three students followed by $3 / 4$ serving having only one student or $0.8 \%$.

Out of 130 students who ordered beans as shown in Table-5, only two or $1.5 \%$ have $1 / 2$ serving of waste and only one has waste of $1 / 4$ serving with a percentage of $0.8 \%$. It only shows that these students that ordered beans dish like the food or maybe because of the cookery used. The substitution of meat with legumes is one way of making food consumption more sustainable according to Lemken, Spiller, and Schulze-Ehlers (2019). In their study of the acceptance of meat with legume products, the result shows that although consumers in New Zealand do not use them regularly, many are open to using meat substitutes made from legumes. It is suggested in the study of Jallinoja, Niva, and Latvala (2016) that for plant proteins to replace meat, new meanings and competences related to preparing and eating pulse-based dishes are needed.

When it comes to tofu, Table- 6 shows that out of 133 students who ordered tofu, only six have waste of $1 / 4$ serving and 127 finished their tofu dish. Soya is known to have high quality nutritional and functional benefits. It is widely used for partial or complete replacement of meat due to its comparative nutrient contents and lesser chances of cardiovascular diseases (Kumar, Chatli, Mehta, Singh, Malav, \& Verma, 2015). In the study of Joshi and Kumar (2015) of meat analogues, they mentioned that the consumption of vegetable proteins in food products has been increasing over the years because of animal diseases, global shortage of animal protein, strong demand for wholesome and religious (halal) food, and economic reasons.

\section{Service Quality of the University Cafeteria}

The tables presented above under the service quality show the results of food service quality questionnaires that were distributed at the second week of observation. A total of 132 questionnaires were given but only 123 questionnaires were analyzed.

In terms of serving time, Table 7 shows that students believe that the cafeteria is serving often on time with a mean of 3.86. Waiting generally is regarded as an undesirable activity that customers must undertake to complete the service. It could lead to both emotional (anger, irritation, and frustration) and behavioral (e.g. abandonment) responses, especially when it is 
costly and limits the person's ability to engage in more productive or rewarding ways to spend time (Djelassi, Diallo, \& Zielke, 2018).

While in terms of personnel services as shown in Table 8, the respondents agree that the cafeteria personnel are properly groomed with a mean of $4.14(\mathrm{SD}=0.74)$ and a verbal interpretation of very good. They also believed that cafeteria personnel are "taking orders from customers" with a mean of $3.82(\mathrm{SD}=1.1)$. The top two lowest results were item number 2 that states "knowledgeable on the food being served" with a mean of $3.57(\mathrm{SD}=0.97)$ and item number 3 that states "good attitude towards customer" with a mean of $3.71(\mathrm{SD}=0.79)$. However, both are still interpreted as very good. Moreover, the standard deviation (SD) is 0.61 which means that the respondents' answers were not far from each other. A survey was conducted among 382 passengers of an airline to examine satisfaction. The results indicate that personnel quality positively affect satisfaction of customers (Koklic, Kukar-Kinney, \& Vegelj, 2017). Moreover, personnel capability and customer satisfaction have a significant positive impact on customer retention. Customer satisfaction partially mediates the effect of personnel capability on customer retention according to the study of Darzi and Bhat (2018).

In Table-9, it shows that the respondents strongly agree that "food served in the cafeteria are healthy" with a mean of $3.79(\mathrm{SD}=0.99)$ and a verbal interpretation of very good. Second highest was item number 1 that says "food served are prepared under sanitary conditions" with a mean of $3.73(\mathrm{SD}=1.05)$ and a verbal interpretation also of very good. However, there are some respondents who do not believe that "food served are delicious" with a mean of 3.34 (SD $=1.08$ ) and a verbal interpretation of good. Second lowest was item number 4 that states, "hot food served hot" with a mean of $3.21(\mathrm{SD}=1.13)$. Thus, the overall result in terms of food quality was interpreted as good having a mean of 3.44. Studies show that food quality has a positive influence on customer retention (Han \& Hyun, 2017; Al-Tit, 2015) .

Table-10 shows the top two highest results with regard to Food Variety. First was item number 1 that states, "food being served offer variety of choices (main dish, vegetable dish, pasta etc.)" having a mean of $4.03(\mathrm{SD}=0.90)$ and a verbal interpretation of very good. Second was item number 4 that says, "there is variety of texture in food items (soft, crunchy, chewy etc.)" with a mean of $3.76(\mathrm{SD}=0.96)$ and a verbal interpretation of very good. The top two lowest results are items number 2 that states, "serving local and international cuisine" and number 5 that states, "there is variety of appearance in food items (different color/presentation)" having a mean of $3.53(\mathrm{SD}=1.09)$ and 3.21 respectively and a verbal interpretation of both good. 
Overall, the respondents believe that cafeteria food variety is very good with a mean of 3.44. According to Ahmad (2015), variety involves the number or assortment of different menu items. Foodservice services constantly develop new menus to entice diners, and many proactive food have created an assortment of food and beverage offerings. Menu items variety was a crucial attribute of food quality in creating dining satisfaction and reduce the food waste. When it comes to the dining area of the cafeteria, Table 11 shows that items number 1,2 , and 3 were the top three (3) highest results. In item_number 1, the respondents believe that "the dining area cleanliness" which is very good (mean of 3.9). Item number 2 that states, "the dining area is attractively structured" with a mean of 3.2 and verbal interpretation of good. The third highest was item number 3 that states "the cafeteria provides cozy environment" with a mean of 2.9 and verbal interpretation of good. While the top three lowest results were items number 6,5 , and 4 . Item number 6 states "music is played during dining time" has a mean of 1.9 and verbal interpretation of fair. Second lowest was item number 5 that states, "the cafeteria provides comfortable seating environment" with a mean of 2.85 and verbal interpretation of good. The third lowest was item number 4 that states, "the school cafeteria is well ventilated" with a mean of 2.89 and verbal interpretation of good. Store atmosphere or ambiance plays an important role in influencing customer behavior. It is suggested in the study of Dabija and Băbuţ (2014) that management of retail chain should pay increased attention to physical surrounding like décor, layout, configurations of merchandise, sounds, aromas, lighting, and floor coverings. Because these will likely gain customer's loyalty more easily.

\section{CONCLUSION}

\section{Food Waste}

Among the five vege-products observed (gluten, grounded vege-scallop, vege-meat, beans, and tofu), gluten has the highest percentage of waste while Tofu has the least food waste.

\section{Food Service Quality}

In terms of service quality as a cafeteria, the researchers conclude that among the five factors affecting the quality service of a food service (Serving Time, Personnel Employee Service, 
Food Variety, Food Quality, and Dining Area), dining area has the lowest average. Most of the factors like Serving time, Personnel Employee Service and Food Variety have a very good result, while Food Quality received good result.

\section{REFERENCES}

Ahmad A. (2015). The effect of service and food quality on customer satisfaction and hence customer retention. Asian social science, 11(23). Canadian center of science and education.

Andersen, B. V., \& Hyldig, G. (2015). Food satisfaction: Integrating feelings before, during and after food intake. Food Quality and Preference, 43, 126-134.

Chang, M. L. D., Suki, N. M., \& Suki, N. M. (2015). Students' Satisfaction with the University Cafeteria: Structural Relationships of Food Quality, Staff, Price Fairness, and Ambiance. Islamic Perspectives Relating to Business, Arts, Culture and Communication, 373-381. doi:10.1007/978-981-287-429-0_35

Cohen JF, Richardson S, Parker E, Catalano PJ, Rimm EB (2014). Impact of the new Department of Agriculture school meal standards on food selection, consumption, and waste.

Crossman, A. (2019). Convenience Samples for Research.

Dabija, D. C., \& Băbuţ, R. (2014). Enhancing consumers' satisfaction and loyalty of retailers in Romania through store ambiance and communication. Procedia Economics and Finance, 15, 371-382.

Darzi, M. A., \& Bhat, S. A. (2018). Personnel capability and customer satisfaction as predictors of customer retention in the banking sector: A mediated-moderation study. International Journal of Bank Marketing, 36(4), 663-679.

Dipesh K. \& Apil P. (2018). How Food Quality, Price, Ambiance and Service Quality Effects Customer Satisfaction: A study on Nepalese Restaurants in Finland. Haaga helia university of applied sciences.

Djelassi, S., Diallo, M. F., \& Zielke, S. (2018). How self-service technology experience evaluation affects waiting time and customer satisfaction? A moderated mediation model. Decision Support Systems, 111, 38-47.

Duong H. (2015). The effect of employee empowerment on service in food service firms. Jamk university of applied science.

Edwards J. (2016). Energy and Time modelling of kerbside waste collection: changes incurred when adding source separated food waste. https://doi.org/10.1016/j.wasman.2016.06.033. 
Food and Agriculture Organization. (2011). Technical Platform on the Measurement and Reduction of Food Loss and Waste. Retrieved from: http://www.fao.org/platformfood-loss-waste/food-waste/definition/en/

Getts, K. M., Quinn, E. L., Johnson, D. B., \& Otten, J. J. (2017). Validity and Interrater Reliability of the Visual Quarter-Waste Method for Assessing Food Waste in Middle School and High School Cafeteria Settings. Journal of the Academy of Nutrition and Dietetics, 117(11), 1816-1821. doi:10.1016/j.jand.2017.05.004.

Hanks, a. S., Wansink, B., \& Just, a. D. (2013). Reliability and Accuracy of real time visualization techniques for measuring cafeteria tray waste: Validating the quarterwaste method. Journal of the academy of nutrition and dietetics, 470-474.

Jallinoja, P., Niva, M., \& Latvala, T. (2016). Future of sustainable eating? Examining the potential for expanding bean eating in a meat-eating culture. Futures, 83, 414. doi:10.1016/j.futures.2016.03.006.

Joshi, V.K., \& Kumar, S. (2015). Meat Analogues: Plant based alternatives to meat productsA review. New Delhi Publishers, India. DOI Number: 10.5958/22779396.2016.00001.5.

Koklic, M. K., Kukar-Kinney, M., \& Vegelj, S. (2017). An investigation of customer satisfaction with low-cost and full-service airline companies. Journal of Business Research, 80, 188-196.

Kumar, P., Chatli, M. K., Mehta, N., Singh, P., Malav, O. P., \& Verma, A. K. (2015). Meat analogues: Health promising sustainable meat substitutes. Critical Reviews in Food Science and Nutrition, 57(5), 923-932. doi:10.1080/10408398.2014.939739.

Lemken, D., Spiller, A., \& Schulze-Ehlers, B. (2019). More room for legume-Consumer acceptance of meat substitution with classic, processed and meat-resembling legume products. Appetite, 104412. doi:10.1016/j.appet.2019.104412.

Rioux L., Schmitt B., \& Leclerc F. (2016). Consumers' reactions to waiting: When delays affect the perception of service quality. Advances in Consumer Research 16, 59-63.

Senduk, D., Saerang, D., \& Lambey, L. (2016). The influence of restaurant ambiance and service quality on customer satisfaction at Pondok Huau Restaurant Manado. Jurnal Berkala Ilmiah Efisiensi, 16(03).

Wilkie, A., Graunke, R., \& Cornejo, C. (2015). Food Waste Auditing at Three Florida Schools. Sustainability, 7(2), 1370-1387. doi:10.3390/su7021370

Zainol, N. A., \& Seladorai, J. (2016). What Matters Most? Factors Influencing International Students' Satisfaction towards Cafeteria Foods. Mediterranean Journal of Social Sciences. doi:10.5901/mjss.2016.v7n4p295 